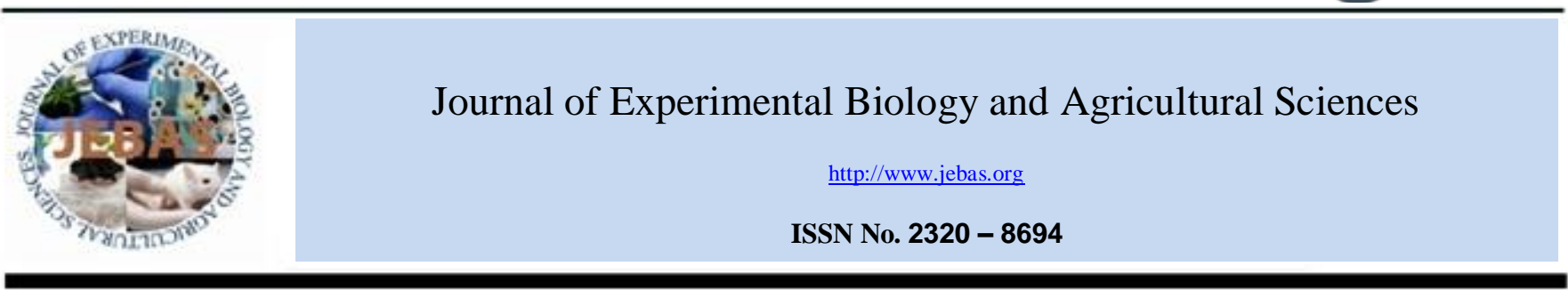

\title{
SELECTING FOR FOOD-FEED TRAITS IN EARLY AND LATE MATURING LENTIL GENOTYPES(Lens culinaris)
}

\author{
Jane Wamatu ${ }^{1, *}$, Asemahegn Mersha ${ }^{2}$, AdugnaTolera ${ }^{2}$, Mohammed Beyan ${ }^{2}$, Ashraf Alkhtib ${ }^{1}$, \\ Million Eshete $^{3}$, Seid Ahmed ${ }^{1}$, Barbara Rischkowsky ${ }^{1}$ \\ ${ }^{1}$ International Center for Agricultural Research in Dry Areas (ICARDA), P.O Box 5689, Addis Ababa, Ethiopia \\ ${ }^{2}$ Hawassa University, P.O Box 5, Hawassa, Ethiopia \\ ${ }^{3}$ Ethiopian Institute of Agricultural Research, DebreZeit Agricultural Research Center, P. O. Box 32, DebreZeit, Ethiopia
}

Received - September 18, 2017; Revision - October 17, 2017; Accepted - October 27, 2017

Available Online - October 31, 2017

http://dx.doi.org/10.18006/2017.5(5).697.705

\section{KEYWORDS \\ Lentil, Straw \\ Nutritive value \\ Genotypic variation \\ Food-feed traits}

\begin{abstract}
To explore genetic and environmental variability of food-feed traits in lentil genotypes, straws of 78elite genotypes and 4 checks of early and late maturing lentil types were evaluated for their nutritive value and potential trade-offs of the nutritive parameters with straw yield and grain yield. Further, effects of genotypic and environmental sources on variation in the nutritive value were also determined. Straw nutritive traits were analyzed by a combination of conventional laboratory techniques and Near Infrared Reflectance Spectroscopy. Results from eight trials carried out across 3 different sites in Ethiopia showed highly significant genotypic variation $(\mathrm{P}<0.05)$ in grain yield, straw yields and straw nutritive traits. This confirmed the existence of exploitable genetic variation in these traits. Similarly, the relationship between grain yield and straw yield was positive. The correlation between grain yield and nutritive parameters of straw was insignificant or negative. The correlation between maturity types and straw traits was either neutral or negative. Genotype by environment interactions were significant $(\mathrm{P}<0.05)$ for straw yield and nutritive traits indicating that variation in the traits is dependent of environment. It is possible to develop genotypes with a combination of food-feed traits from early and late maturing lentil types to address the high demand for grain and livestock fodder in various agro ecological zones in mixed crop-livestock farming systems using appropriate breeding approaches.
\end{abstract}

* Corresponding author

E-mail: j.wamatu@cgiar.org (Jane Wamatu)

Peer review under responsibility of Journal of Experimental Biology and Agricultural Sciences.

Production and Hosting by Horizon Publisher India [HPI] (http://www.horizonpublisherindia.in/).

All rights reserved.
All the article published by Journal of Experimental Biology and Agricultural Sciences is licensed under a Creative Commons Attribution-NonCommercial 4.0 International License Based on a work at www.jebas.org.

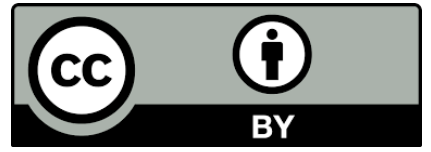




\section{Introduction}

Lentil (Lens culinaris) is an annual cool-season legume primarily used for human consumption and the straw used as livestock feed. The major lentil-growing countries of the world are Canada, India, Turkey, Australia, USA, Nepal, Bangladesh, China and Ethiopia (FAOSTAT, 2014). Ethiopia covers $69.4 \%$ of the areas devoted to lentil and $81.5 \%$ of the total production in Africa (FAOSTAT, 2014). In 2016, lentil was produced by over 850,000 small holder households and covered about 114,000 ha with an average productivity of $1.5 \mathrm{t} / \mathrm{ha}$ (CSA, 2017). The International Center for Agricultural Research in the Dry Areas (ICARDA) has a world mandate for lentil improvement and is working with national programs across several countries to enhance production and productivity, increase incomes of farmers and provide lentil to consumers for food and nutritional security. Understanding of genotype by environment interactions, local constraints to production and consumer requirements for seed as food and straw as feed, has been a guide to the national and international breeding programs to develop new genetic materials for various agroecologies in West Asia, North and East Africa region. In the predominant mixed crop-livestock systems of Ethiopian highlands, lentil straw is among fibrous crop residues from cereals and legumes that constitute large proportions of livestock feeds, particularly, during dry seasons (Valbuena et al., 2012). Lentil straw has been reported to have better degradation in the rumen
(Singh et al., 2011) and higher concentrations of crude protein and digestible energy (Hadjipanayiotou, 1997) than cereal straws routinely used as fodder. Similarly, high acceptability and digestibility of lentil straw in ration of livestock was also reported by Abbeddou et al. (2011). Since lentil straw is valorized mainly in ruminant nutrition, it is important that its nutritive value is as high as possible. This offers an opportunity for livestock nutritionists and lentil breeders to collaboratively explore the feasibility of genetic enhancement of not only grain traits but also straw yield and its nutritive value. Exploitable genetic variability among lentil genotypes has been reported for straw yield (Kusmenoglu \& Muehlbauer, 1998) and nutritive value (Erskine et al., 1990). However, these studies were undertaken in single environments, thus, there is need to support them with additional studies across various locations and populations of different maturity types so as to draw concrete conclusions on genetic variability and food-feed trait relationships. Differences in phenological development in lentil contributes $45-60 \%$ of the variation in grain yield (Siddique et al., 1998; Shrestha et al., 2006). Ghanem et al. (2015) indicated that selection and breeding for lentil accessions should consider changes in plant phenology and/or sowing dates. Therefore, the current study aimed to determine the variabilityof straw traits and food-feed relationships in early and late maturing lentil genotypes developed for locations with varying rainfall patterns in Ethiopia. Results from this study can be further explored to select for

Table 1 Experimental design of 8 trials across 3 sites in Ethiopia

\begin{tabular}{|c|c|c|c|c|c|}
\hline \multirow{2}{*}{ Trial Code } & \multirow{2}{*}{ Location } & \multirow{2}{*}{ Populations } & \multicolumn{3}{|c|}{$\mathrm{N}$} \\
\hline & & & Blocks & Genotypes & Observations \\
\hline NVT-LMS-DZ & DebreZeit & Early maturing & 4 & 16 & 64 \\
\hline PVT-LMS-DZ & DebreZeit & Early maturing & 3 & 25 & 75 \\
\hline NVT-PE-AK* & Akaki & Late maturing & 4 & 16 & 64 \\
\hline NVT-PE-CD* & ChefeDonsa & Late maturing & 4 & 16 & 64 \\
\hline NVT-PE-DZ* & DebreZeit & Late maturing & 4 & 16 & 64 \\
\hline PVT-PE-AK ${ }^{\dagger}$ & Akaki & Late maturing & 3 & 25 & 75 \\
\hline PVT-PE-CD ${ }^{\dagger}$ & ChefeDonsa & Late maturing & 3 & 25 & 75 \\
\hline PVT-PE-DZ ${ }^{\dagger}$ & DebreZeit & Late maturing & 3 & 25 & 72 \\
\hline
\end{tabular}

$* \dagger+\S$ : trials with different symbols differ in genotypes, PVT: preliminary variety trial; NVT: national variety trial, LMS: low moisture stress environments, PE: potential environments, DZ, DebreZeit, AK: Akaki, CD, ChefeDonsa.

\section{Journal of Experimental Biology and Agriculture Science} http://www.jebas.org 
food-feed traits in pre-released lines of lentil.

\section{Materials and methods}

\subsection{Experimental layout and lentil genotypes}

Eight field trials (Table 1) were conducted in 3 sites namely Akaki(AK; $\left.08^{\circ} 53^{\prime} \mathrm{N} 38^{\circ} 49^{\prime} \mathrm{E}\right)$, DebreZeit (DZ; 08 $\left.{ }^{\circ} 44^{\prime} \mathrm{N} 3858^{\prime} \mathrm{E}\right)$, and Chefe Donsa (CD; $\left.08^{\circ} 57^{\prime} \mathrm{N} 39^{\circ} 06^{\prime} \mathrm{E}\right)$ in Ethiopia. Akaki, DebreZeit and ChefeDonsa are located in Central Ethiopian Highlands at altitudes of 2200, 1900 and 2400 m.a.s.l and average annual rainfall reported to be $1025 \mathrm{~mm}, 851 \mathrm{~mm}$ and $878 \mathrm{~mm}$ respectively. Soils of the studied sites are vertisols. All the experimental sites and trials were preceded by wheat crops. Trials were undertaken during the main rainy season of 2014/15 cropping seasons. Elite genotypes were collected from 2014 preliminary variety trials(PVT) and national variety trials (NVT)of the Ethiopian Lentil Improvement Program. These genotypes were selected on the basis of their high grain yield, agronomic traits in potential environments (PE) and low moisture stress environments (LMS).These genotypes were selected from ICARDA breeding lines sent to the Ethiopian Institute for Agricultural Research through its international nurseries platform. A total of 82 lentil genotypes (78 elite lines and 4 checks) were evaluated for the study on food and feed traits. The 8 trials are identified by their codes (Table 1) which indicate which variety trials the genotypes were drawn from (PVT, NVT), the type of environment they were planted in (PE, LMS) and the locations where they were planted (AK, DZ, CD).The design was randomized complete block design with either three or four replications (Table 1) depending on the trial. The plot size was 3.2 $\mathrm{m}^{2}$ with four rows in all trials. At physiological maturity, two middle rows were manually harvested. The biomass was air-dried in the field and threshed for seed and straw yields. Straw yield was calculated based on harvest index. Sub-samples of $500 \mathrm{~g}$ of representative straw were taken from each plot for chemical composition and digestibility analyses.

\subsection{Nutritive analysis of straw}

Laboratory analyses were undertaken at the Animal Nutrition Laboratories of the International Livestock Research Institute (ILRI), Addis Ababa, Ethiopia and Patencheru, India. After ovendrying at $100^{\circ} \mathrm{C}$ for $24 \mathrm{~h}$, straw samples were ground to pass through a $1 \mathrm{~mm}$ sieve mesh. The samples were analyzed using Near Infrared Reflectance Spectroscopy (NIRS) and conventional wet chemistry. The NIRS instrument, Foss Forage Analyzer 5000 with the software package WinISI II in the 1108-2492 nm spectra range was used to scan lentil straw samples and a good-of-fitness lentil NIRS equation was used for the prediction of dry matter
(DM), nitrogen, neutral detergent fiber (NDF) and in vitro digestibility (IVOMD). Validation of the NIRS equation was undertaken using conventional wet chemistry, whereby $20 \%$ representative samples were analyzed for DM and crude protein (CP) according to the methodology of AOAC (2000). Dry matter was determined by oven drying at $105^{\circ} \mathrm{C}$ overnight (method 934.01). Ash was determined by burning in a muffle furnace at $500^{\circ} \mathrm{C}$ overnight (method 942.05). Nitrogen content was determined by Kjeldahl method using Kjeldahl (protein/nitrogen) Model 1026 (Foss Technology Corp.), (method 954.01). A conversion factor of 6.25 was used to convert nitrogen to crude protein. Neutral detergent fiber, acid detergent fiber (ADF) and lignin were determined as described by Van Soest \& Robertson (1985). Neutral detergent fiber did not involve use of heat stable amylase and the result was expressed exclusive of residual ash. Acid detergent fiber was expressed without residual ash. Lignin was determined by solubilisation of cellulose with sulphuric acid. In vitro organic matter digestibility was measured in rumen microbial inoculum using in vitro gas production technique. The buffer solution was prepared according to the method described by Menke \& Steingass (1988). Rumen fluid was collected prior to morning feeding using a vacuum pump from three ruminally cannulated cows fed a total mixed ration of grass hay $(790 \mathrm{~g} / \mathrm{kg})$, wheat bran $(203 \mathrm{~g} / \mathrm{kg})$, salt $(3.2 \mathrm{~g} / \mathrm{kg})$ and a mineral and vitamin mixture $(4.6 \mathrm{~g} / \mathrm{kg})$ on a DM basis. Use of cows was assessed and approved by the Environmental and Occupational Health and Safety Unit of ILRI. The rumen fluid from the cows was composited $(1: 1, \mathrm{v} / \mathrm{v})$, filtered through four layers of cheesecloth, and added to the buffer solution $(1: 2, \mathrm{v} / \mathrm{v})$, which was maintained in a water bath at $39^{\circ} \mathrm{C}$ under continuous flushing with $\mathrm{CO}_{2}$. The buffered rumen fluid $(30 \mathrm{ml})$ was pipetted into $100 \mathrm{ml}$ syringes containing $0.2 \mathrm{~g}$ of sample and immediately placed into a water bath at $39^{\circ} \mathrm{C}$. Gas production was recorded after 24 hours of incubation and used to calculate IVOMD according to Menke et al. (1979) equations suitable for legume hays as follows:

$$
\operatorname{IVOMD}(\mathrm{g} / \mathrm{kg})=14.88+0.889 \mathrm{GP}+0.45 \mathrm{CP}+0.0651 \mathrm{XA}
$$

Where GP: $24 \mathrm{~h}$ net gas production $(\mathrm{ml} / 200 \mathrm{mg})$; CP: Crude protein (g/kg DM); XA: Ash content (g/kg DM).

\subsection{Calculations and statistical analysis}

A general linear model was used to test the effect of variety on grain yield, straw yield and nutritive value parameters of straw. Each trial was analyzed separately according to the following model (Ertiro et al., 2013):

$Y_{i j}=\mu+B_{i}+G_{j}+E_{i j}$

\section{Journal of Experimental Biology and Agriculture Science} http://www.jebas.org 
Where: $Y_{i j}$ : grain/straw traits, $\mu$ : overall mean, $B_{i}$ : effect of the block $\mathrm{i}, \mathrm{G}_{\mathrm{j} \text { : }}$ effect of the genotype $\mathrm{j}, \mathrm{E}_{\mathrm{ij}}$ : random error.To evaluate the effect of location and genotype-location interaction $(\mathrm{GxL})$, data from all trials combined and analyzed according to the following model (Ertiro et al., 2013):

$$
Y_{i j k}=\mu+G_{i}+L_{j}+G L_{i j}+B(L)_{i j}+E_{i j k}
$$

Where: $Y_{i j}$ grain/straw traits, $\mu$ : overall mean, $G_{i}$ : effect of the genotype $\mathrm{i}, \mathrm{L}_{\mathrm{j}}$ : effect of location $\mathrm{j}$, GL $\mathrm{Gij}_{\mathrm{ij}}$ : effect of interaction between the genotype and location, $B(L) i j:$ effect of block i within location $\mathrm{j}, \mathrm{E}_{\mathrm{ijk}}$ : random error. Relationships between grain and straw traits were calculated separately for each trial using Pearson's correlation.

Principal component analysis (PCA) was used to simultaneously evaluate mean differences to quantify the contribution of each constituent to the variation in nutritive values. Crude protein, $\mathrm{NDF}$, and IVOMD are major determinants of nutritive value of straw, thus were included in PCA. Neutral detergent fiber is reported to negatively correlate to dry matter intake (Horrocks \& Vallentine, 1999), while IVOMD positively correlates to ME. The sign and magnitude of eigenvectors were examined for their relevance in explaining the nutritive value of straw. All eigenvectors were standardized to unite the variance. Principle component analysis was performed for each group of genotypes separately.

All statistical procedures were carried out using Statistical Analysis System software (SAS, 2012).

\section{Results}

3.1 Variations of genotypes for time to maturity, grain and straw yields

Grain and straw yields of individual trials showed significant genotypic variations $(\mathrm{P}<0.05)$ in all trials (Table 2$)$. Mean squares of location and GXL interaction are presented in Table 4. The effect of location and GXL interaction on grain and straw yields was significant $(\mathrm{P}<0.05)$ in trials of late maturing genotypes (Table 4). The highest grand means for both grain (2.82 t/ha) and straw yields $(6.43 \mathrm{t} / \mathrm{ha})$ were from PVT-PE-CD. The lowest grand means for grain $(0.982 \mathrm{t} / \mathrm{ha})$ and straw yields $(3.07 \mathrm{t} / \mathrm{ha})$ were from NVT-PE-DZ and NVT-PE-AK respectively. Considering genotypes in individual trials, the widest range of grain yield from $0.28 \mathrm{t} / \mathrm{h}$ a to $2.61 \mathrm{t} / \mathrm{ha}$ was from NVT-PE-DZ while PVT-PE-CD showed the widest range of straw yield from $3.22 \mathrm{t} / \mathrm{ha}$ to $9.33 \mathrm{t} / \mathrm{ha}$.

Table 2 Means and ranges of grain yield, straw yield and days to maturity of lentil genotypes in 8 trials across 3 locations.

\begin{tabular}{|c|c|c|c|c|c|c|c|c|c|}
\hline \multirow{2}{*}{ Trial } & \multicolumn{3}{|c|}{ Grain yield (t/ha) } & \multicolumn{3}{|c|}{ Straw yield ( $\mathrm{t} / \mathrm{ha}$ ) } & \multicolumn{3}{|c|}{ Maturity (days) } \\
\hline & Range & Mean & SEM & Range & Mean & SEM & Range & Mean & SEM \\
\hline \multicolumn{10}{|l|}{ Early maturing } \\
\hline NVT-LMS-DZ & $0.482-2$ & 1.37 & 0.08 & $2.71-4.7$ & 3.62 & 0.60 & $81-92$ & 88.6 & 0.83 \\
\hline PVT-LMS-DZ & $0.74-2.04$ & 1.25 & 0.16 & $2.78-5.43$ & 3.48 & 0.32 & $77-99$ & 83.2 & 1.96 \\
\hline \multicolumn{10}{|l|}{ Late maturing } \\
\hline NVT-PE-AK & $0.72-2.72$ & 1.65 & 0.20 & $2.17-4.4$ & 3.07 & 0.39 & $100-126$ & $130 \dagger$ & 1.33 \\
\hline NVT-PE-CD & $1.62-3.11$ & 2.24 & 0.10 & $3.15-8.22$ & 5.83 & 0.32 & $107-133$ & 121 & 1.17 \\
\hline NVT-PE-DZ & $0.28-2.61$ & 0.982 & 0.15 & $2.38-5.2$ & 3.64 & 0.32 & $75-115$ & 96.6 & 2.2 \\
\hline PVT-PE-AK & $0.404-2.32$ & 1.62 & 0.16 & $1.68-4.93$ & 3.12 & 0.34 & $97-123$ & 111 & 2.32 \\
\hline PVT-PE-CD & $1.91-3.71$ & 2.82 & 0.32 & 3.22-9.33 & 6.43 & 0.61 & 106-139 & 122 & 1.2 \\
\hline PVT-PE-DZ & $0.401-2.01$ & 1.1 & 0.16 & $2.62-5.43$ & 3.92 & 0.39 & $80-115$ & 94.5 & 1 \\
\hline
\end{tabular}

$\dagger: \mathrm{P}>0.05$ otherwise $\mathrm{P} \leq 0.05$, PVT: preliminary variety trial; NVT: national variety trial, LMS: low moisture stress environments, PE: potential environments, DZ, DebreZeit, AK: Akaki, CD, ChefeDonsa.

\section{Journal of Experimental Biology and Agriculture Science http://www.jebas.org}


Table 3 Means and ranges of crude protein,NDF and in vitro organic matter digestibility of lentil genotypes in 8 trials across 3 locations

\begin{tabular}{|c|c|c|c|c|c|c|c|c|c|}
\hline \multirow[t]{2}{*}{ Trial } & \multicolumn{3}{|c|}{ Crude protein (g/kg DM) } & \multicolumn{3}{|c|}{ IVOMD (\%) } & \multicolumn{3}{|c|}{$\mathrm{NDF}(\mathrm{g} / \mathrm{kg})$} \\
\hline & Range & Mean & SEM & Range & Mean & SEM & Range & Mean & SEM \\
\hline \multicolumn{10}{|l|}{ Early maturing } \\
\hline NVT-LMS-DZ & $80.3-104$ & $90.1 \dagger$ & 7.0 & $53.1-57$ & $55 \dagger$ & 1.2 .2 & $487-550$ & $521 \dagger$ & 19.9 \\
\hline PVT-LMS-DZ & $77.5-119$ & 100 & 6.2 & $53.9-62$ & 57.1 & 1.18 & $411-560$ & 471 & 20.4 \\
\hline \multicolumn{10}{|l|}{ Late maturing } \\
\hline NVT-PE-AK & 48-94 & 77 & 2.8 & $54-62.4$ & 58.4 & 0.59 & $390-520$ & 445 & 10.7 \\
\hline NVT-PE-CD & $47.8-78.3$ & 65.2 & 3.0 & $52-61.4$ & 57.1 & 0.61 & $432-562$ & 488 & 8.7 \\
\hline NVT-PE-DZ & $79.5-136$ & 111 & 6.3 & $50.2-59.1$ & 55.6 & 1.06 & $435-617$ & 517 & 21.3 \\
\hline PVT-PE-AK & $60.4-91.7$ & $74.3 \dagger$ & 9.6 & 52.3-61.9 & $57.9 \dagger$ & 1.96 & $410-579$ & $468 \dagger$ & 30.1 \\
\hline PVT-PE-CD & $38.2-80.3$ & 57.4 & 3.9 & $53.2-61.4$ & 56.8 & 0.9 & $438-550$ & 496 & 11.4 \\
\hline PVT-PE-DZ & $83.5-148$ & 114 & 4.6 & $55.1-60.5$ & 58 & 0.82 & $450-544$ & 498 & 12.8 \\
\hline
\end{tabular}

CP: crude protein, NDF: neutral detergent fiber, IVOMD: in vitro organic matter digestibility, $\uparrow: \mathrm{P}>0.05$ otherwise $\mathrm{P} \leq 0.05$, $\mathrm{PVT}$ : preliminary variety trial; NVT: national variety trial, LMS: low moisture stress environments, PE: potential environments, DZ, DebreZeit, AK: Akaki, CD, ChefeDonsa.

Maturity type showed significant genotypic variation in all trials except NVT-PE-AK. The effect of the location on maturity type was significant in PVTs and NVTs. Considering genotypes in individual trials, the widest range of maturity was found in NVTPE-DZ (40 days).

\subsection{Variations in straw nutritive traits}

Table 3 shows trial means and ranges for straw nutritive traits (CP, NDF and IVOMD). The variation among genotypes for CP, NDF and IVOMD was significant $(\mathrm{P}<0.05)$ in all trials except NVT-LMS-DZ and PVT-PE-AK. The effect of location and GXL on nutritive traits was significant $(\mathrm{P}<0.05)$ for late maturing genotypes (Table 4). The means of trials for CP ranged from 57.4 $\mathrm{g} / \mathrm{kg}$ DM in PVT-PE-CD to $114 \mathrm{~g} / \mathrm{kg}$ DM in PVT-PE-DZ. The highest range within trials was found in PVT-PE-DZ with $64.5 \mathrm{~g} / \mathrm{kg}$ DM. The genotype with highest (148 g/kg DM) and lowest CP (38.2 g/kg DM) was observed from NVT-PE-DZ and PVT-PE-CD respectively. The grand means of trials for IVOMD ranged from $55 \%$ in NVT-LMS-DZ to $58.4 \%$ in NVT-PE-AK (Table 3). The highest range within trials was found in PVT-PEAK from $52.3 \%$ to $61.9 \%$. The genotypes with highest $(62.4 \%)$ and lowest (50.2\%) IVOMD were observed from NVT-PE-AK
Table 4 Mean squares of location and genotype by environment interaction for grain yield, straw yield and nutritive traits of straws in 6 late maturing genotypes trials

\begin{tabular}{|c|c|c|}
\hline \multirow{2}{*}{ Parameters } & \multicolumn{2}{|c|}{ Source of variance } \\
\hline & Location & $\mathrm{G} \times \mathrm{L}$ \\
\hline Grain yield & 63.8 & 0.594 \\
\hline Maturity & 18726 & $2398 \dagger$ \\
\hline Straw yield & 257 & 3.7 \\
\hline $\mathrm{CP}$ & 77073 & 327 \\
\hline NDF & 59668 & 2519 \\
\hline IVOMD & 3517 & 1362 \\
\hline $\begin{array}{l}\text { GxL: genotype-lo } \\
\text { neutral detergen } \\
\text { digestibility, } \dagger: P>0\end{array}$ & $\begin{array}{l}\text { raction, CP: } \\
\text { OMD: in } \\
\text { se } \mathrm{P} \leq 0.05 \text {. }\end{array}$ & $\begin{array}{c}\text { protein, } \\
\text { organic } \mathrm{m}\end{array}$ \\
\hline
\end{tabular}


and NVT-PE-DZ respectively. The grand means of trials for NDF ranged from $445 \mathrm{~g} / \mathrm{kg}$ DM in NVT-PE-AK to $521 \mathrm{~g} / \mathrm{kg} \mathrm{DM}$ in NVT-LMS-DZ. The highest range within trials was found in NVT-PE-DZ with $182 \mathrm{~g} / \mathrm{kg}$ DM. The genotype with highest (617 $\mathrm{g} / \mathrm{kg} \mathrm{DM}$ ) and lowest NDF (390 g/kg DM) was from NVT-PE-DZ and NVT-PE-AK respectively.

\subsection{Principle component analysis}

Results of PCA are showed in Table 5 where PC1 and PC2 cumulatively accounted for more than $90 \%$ of the variation. In all populations, PC1 accounted for $64 \%$ to $76 \%$ of the variance, which was the highest among the PCAs. An examination of the eigenvectors showed that $\mathrm{PC} 2$ consistently showed negative sign for IVOMD and a positive sign for NDF in all genotypes, whereas PC1 showed a positive sign for IVOMD and a negative sign for NDF. In all genotypes populations, IVOMD had the highest magnitude among the eigenvectors followed by NDF then CP.

\subsection{The correlation between maturity, grain and straw yields}

The correlation between grain yield and straw yield was not consistent across trials as shown in Table 6. Grain yield correlated moderately and positively to straw yield in early maturing
Table 5Principle component analysis of nutritive parameters of straw

\begin{tabular}{|c|c|c|c|}
\hline Type & Statistics & Pc1 & Pc2 \\
\hline \multicolumn{4}{|c|}{ Early maturing } \\
\hline & $\begin{array}{l}\text { Eigenvalue } \\
\text { (variation explained) }\end{array}$ & $2.24(0.75)$ & $0.66(0.22)$ \\
\hline & \multicolumn{3}{|l|}{ Eigenvectors } \\
\hline & $\mathrm{CP}$ & 0.524 & 0.744 \\
\hline & NDF & -0.551 & 0.667 \\
\hline & IVOMD & 0.648 & -0.034 \\
\hline \multicolumn{4}{|c|}{ Late maturing } \\
\hline & \multicolumn{3}{|l|}{$\begin{array}{l}\text { Eigenvalue } \\
\text { (variation explained) }\end{array}$} \\
\hline & Eigenvectors & $1.99(0.66)$ & $0.879(0.29)$ \\
\hline & $\mathrm{CP}$ & 0.358 & 0.918 \\
\hline & NDF & -0.641 & 0.373 \\
\hline & IVOMD & 0.678 & -0.131 \\
\hline
\end{tabular}

CP: crude protein, NDF: neutral detergent fiber, IVOMD: in vitro organic matter digestibility.

Table 6 Pearson correlation between grain yield and days to maturity with straw traits

\begin{tabular}{|c|c|c|c|c|c|c|c|c|}
\hline \multirow{2}{*}{ Trials } & \multicolumn{4}{|c|}{ Grain yield } & \multicolumn{4}{|c|}{ Days to maturity } \\
\hline & Straw yield & IVOMD & $\mathrm{CP}$ & $\mathrm{NDF}$ & Straw yield & IVOMD & $\mathrm{CP}$ & $\mathrm{NDF}$ \\
\hline \multicolumn{9}{|l|}{ Early maturing } \\
\hline NVT-LMS-DZ & 0.391 & $\mathrm{~ns}$ & $\mathrm{~ns}$ & $\mathrm{~ns}$ & $\mathrm{~ns}$ & Ns & $\mathrm{ns}$ & $\mathrm{ns}$ \\
\hline PVT-LMS-DZ & 0.372 & ns & -0.672 & -0.4 & 0.684 & 0.388 & ns & -0.764 \\
\hline \multicolumn{9}{|l|}{ Late maturing } \\
\hline NVT-PE-AK & $\mathrm{ns}$ & -0.772 & -0.722 & 0.571 & $\mathrm{~ns}$ & Ns & ns & $\mathrm{ns}$ \\
\hline NVT-PE-CD & $\mathrm{ns}$ & -0.473 & -0.512 & 0.452 & 0.83 & 0.69 & 0.61 & -0.8 \\
\hline NVT-PE-DZ & 0.413 & -0.381 & -0.652 & ns & $\mathrm{ns}$ & 0.3 & 0.59 & -0.449 \\
\hline PVT-PE-AK & $\mathrm{ns}$ & $\mathrm{ns}$ & $\mathrm{ns}$ & $\mathrm{ns}$ & 0.583 & 0.228 & 0.263 & -0.29 \\
\hline PVT-PE-CD & ns & ns & ns & ns & 0.76 & 0.53 & 0.44 & -0.6 \\
\hline PVT-PE-DZ & 0.452 & $\mathrm{~ns}$ & -0.691 & -0.291 & $\mathrm{~ns}$ & 0.353 & 0.299 & -0.539 \\
\hline
\end{tabular}

CP: crude protein, NDF: neutral detergent fiber, IVOMD: in vitro organic matter digestibility, ns: non-significant at $\mathrm{P}<0.05$ otherwise $\mathrm{P} \leq 0.05$, PVT: preliminary variety trial; NVT: national variety trial, LMS: low moisture stress environments, PE: potential environments, DZ, DebreZeit, AK: Akaki, CD, ChefeDonsa.

\section{Journal of Experimental Biology and Agriculture Science http://www.jebas.org}


genotypes. In late maturing genotypes, grain yield related moderately and positively to straw yield in DebreZeit location. The correlation between grain yield and IVOMD was negative and strong in NVT-PE-AK and negative and moderate in NVTPE-CD and NVT-PE-DZ. Crude protein correlated strongly and inversely to grain yield in PVT-LMS-DZ, NVT-PE-, NVT-PEand PVT-PE-DZ. The correlation between grain yield and CP was inverse and moderate in NVT-PE-CD. Grain yield correlated inversely and moderately to NDF in PVT-LMS-DZ, NVT-PE-AK and NVT-PE-CD. A weak and positive correlation between grain yield and NDF was found in PVT-PE-DZ. Maturity correlated strongly to straw yield in PVT-LMS-DZ, NVT-PE-CD and PVTPE-CD. PVT-PE-AK showed moderate and positive correlation between maturity and straw yield. Maturity showed either insignificant or positive correlation with $\mathrm{CP}$ and IVOMD.

\section{Discussion}

\subsection{Grain and straw yield}

In mixed crop-livestock systems, increasing crop residue biomass tends to improve milk and meat production of livestock. The wide genetic variation in grain and straw yields in all trials in this study are in agreement with what was reported by Bidinger et al. (2010) in pearl millet and Ertiro et al. (2013) in maize. The results of this study showed that yields of grain and straw in late maturing lentil genotypes were affected by location. Ertiro et al. (2013) showed similar GXL interactions in grain and stover yield of maize. It implies the possibility of increasing both grain and straw yield of lentil by improving agronomic practices. Though lentil improvement programs target grain yield as a primary trait, the large variability that exists among genotypes for both grain and straw yield as shown in this study suggests that breeding programs can exploit the variability for improvement of grain and straw production. However, such programs need to be location-specific. The GXL interaction in early maturing genotypes of lentil was not studied in this study. Thus, further studies need to identify the relationship between the environment and grain and straw production of early maturing genotypes of lentil.

\subsection{Straw nutritive traits}

All genotypes in the two maturity groups showed a wide range in nutritive value parameters of straw. Others studies in maize (Tolera et al., 1998; Ertiro et al., 2013), durum wheat (Tolera et al., 2008), pearl millet (Blummel et al., 2007; Blummel et al., 2010a) and sorghum (Blummel et al., 2010b) also showed wide variations in straw nutritive values. Crude protein content in feeds is important to achieve optimal rumen activity. Risco \& Melendez (2011) recommended that a minimum of $70-80 \mathrm{~g} / \mathrm{kg}$ and $100-110$ $\mathrm{g} / \mathrm{kg}$ of $\mathrm{CP}$ in rations of non-lactating and lactating animals respectively, are required to sustain rumen fermentation. The grand means of CP in 7 trials out of 8 were higher than $70 \mathrm{~g} / \mathrm{kg}$. Moreover, genotypes with the lowest $\mathrm{CP}$ across 5 trials had values higher than $70 \mathrm{~g} / \mathrm{kg}$ while grand means of $\mathrm{CP}$ of 3 trials exceeded the minimum recommendation for lactating animals. The nutritive value of lentil straw was reported to be greater than vetch and wheat straw and close to the nutritive value of alfalfa hay when fed to Awassi sheep (Haddad \& Husein, 2001).The highest CP content in this study $(148 \mathrm{~g} / \mathrm{kg})$ is equivalent to that of good quality hay. The wide genetic variation in NDF is indicative of wide variation in potential dry matter intake as NDF and dry matter intake of feed are closely related. Accordingly, the nutritive value of lentil straw can be improved by exploiting the natural genotypic variations. The significant effect of location on nutritive value of straw suggests the possibility to improve nutritive value of lentil straw by manipulating agronomic factors. All nutritive parameters had significant GXL interactions indicating that the genotypic variation in the traits is dependent of environment. This interaction should be considered in any improvement program that targets increasing the nutritive value of lentil straw.

\subsection{Principle component analysis}

Principle component analysis was carried out to investigate the possibility of minimizing parameters representing nutritive value of lentil straw. Crude protein and IVOMD are expected to contribute positively to nutritive value and are, therefore, expected to have positive signs. Similarly, NDF is expected to have a negative sign because it contributes negatively to nutritive value. PC1 showed that NDF and IVOMD can represent the nutritive value of both early maturing and late maturing genotypes as their eigenvectors were both of high magnitude and had negative and positive signs respectively. However, NDF is preferred because the procedure to determine it in the laboratory is simpler compared to IVOMD. Therefore, NDF can represent the nutritive value of lentil straw and can be used for screening genotypes for nutritive value. The nutritive value of lentil straw can be improved by breeding genotypes which have straw with low NDF content. Our results agree with Alkhtib et al. (2016) who found out that principle component analysis score can be used to summarize the nutritive value of faba bean straw.

\subsection{Relationship between grain and straw traits}

Grain yield is the main trait targeted by improvement programs of lentil. Thus, it is imperative that selection of lentil genotypes for better straw traits does not compromise grain yield. The

\section{Journal of Experimental Biology and Agriculture Science} http://www.jebas.org 
correlation between grain yield, straw yield and nutritive value of straw was not consistent across trials. However, no negative correlation between grain yield and straw yield was found in any trial. That means there are no tradeoffs between grain yield and straw yield, thus, breeding lentil for increased grain production would not have detrimental effects on straw yield. However, straw yield cannot be predicted from grain yield because the correlations were moderate $\left(\mathrm{R}^{2} \leq 0.2\right)$. The correlations between grain yield and nutritive value parameters were also inconsistent. There were trials which exhibited insignificant correlations with grain yield indicating that there is potential to identify genotypes within particular environments that have no tradeoffs between increasing grain yield and nutritive value of straw. These results concur with findings of previous studies reported in faba bean (Alkhtib et al., 2016), pearl millet (Blummel et al., 2010a) and sorghum (Blummel et al., 2010b) and which reported that selection of genotypes to achieve high grain yield did not depress the digestibility and energy content of straw. Most of the trials showed positive and high correlations between maturity type and straw yield as well as maturity type and nutritive value. That means breeding for early maturity could be associated with a decline in straw yield and nutritive value parameters. However, neutral relations in some of the trials indicate the possibility of finding early maturing genotypes with superior food-feed traits.

\section{Conclusion}

Mixed crop-livestock systems, the backbone of both animal and crop agriculture in developing countries, are characterized by smallholder farmers. In these closely integrated production systems, particularly those in the highlands, cereal and legume straws are predominantly used to supplement feed for livestock. As important as it is to increase straw production, is it critical to enhance the nutritive value of the straw. Nutritive value is likely to exert effects on voluntary intake and digestibility of dry matter in livestock. Therefore, incorporating straw nutritive traits in lentil breeding programs and varietal release criteria holds promise for enhanced livestock productivity in smallholder mixed farming systems.

\section{Acknowledgement}

The authors would like to acknowledge the financial support from the CGIAR Collaborative Research Program, Livestock \& Fish and the USAID-funded, Feed the Future initiative, Africa Research in Sustainable Intensification for the Next Generation (Africa RISING). Appreciation to Ethiopian Institute for Agricultural Research, DebreZeit Station for facilitating field activities and to the Animal Nutrition Laboratory of the
International Livestock Research Institute (ILRI) in Addis Ababa, Ethiopia and Patancheru, India for analyses of straw samples.

\section{Conflict of Interest}

The authors declare that they have no conflict of interest regarding the publication of this paper.

\section{References}

Abbeddou S, Rihawi S, Hess H, Iniguez L, Mayer A, Kreuzer M (2011) Nutritional composition of lentil straw vetch hay olive leaves and saltbush leaves and their digestibility as measured in fat-tailed sheep.Small Ruminant Research 96: 126-135.

AOAC (2000)Official Methods of Analysis.17 $7^{\text {th }}$ ed. Association of Official Analytical Chemists Gaithersburg USA.

Alkhtib A, Wamatu J, Wegi T, Rischkowsky B (2016) Variation in the straw traits of morphological fractions of faba bean (Vicia faba L.) and implications for selecting for food-feed varieties. Animal Feed Science and Technology 222: 122-131.

Bidinger FR, Blummel M, Hash CT, Choudhary S (2010) Genetic enhancement for superior food-feed traits in a pearl millet (Pennisetumglaucum $(\mathrm{L}) \quad \mathrm{R}$. Br.) variety by recurrent selection. Animal Nutrition and Feed Technology 10S: 61-68.

Blummel M, Bidinger F, Hash C (2007) Management and cultivar effects on ruminant nutritional quality of pearl millet (Pennisetum glaucum) stover. II. Effects of cultivar choice on stover quality and productivity. Field Crops Research 103: 129-138.

Blummel M, Khan A, Vadez V, Hash C, Rai K (2010a) Variability in stover quality traits in commercial hybrids of pearl millet (Pennisetum glaucum (L.) R. Br.) and grain-stover trait relationships. Animal Nutrition and Feed Technology 10S: 29-38.

Blummel M, Vishala A, Ravi D, Prasad K, Reddy C, Seetharama N (2010b) Multi-environmental investigations of food-feed trait relationships in Khalif and Rabi sorghum (Sorghum bicolour(L)Moench) over several years of cultivar testing in India. Animal Nutrition and Feed Technology 10S: 11-21.

CSA (2017)Agricultural Sample Survey Report on: Area and Production of CropsStatistical Bulletin.Central Statistical Agency,Addis Ababa, Ethiopia.

Erskine W, Rihawi S, Capper E (1990) Variation in lentil straw nutritive. Animal Feed Science and Technology 28: 61-69.

\section{Journal of Experimental Biology and Agriculture Science http://www.jebas.org}


Ertiro T, Twumasi-Afriyie S,Blummel M, Friesen D, Negera D, Worku M, Abakemal M, Kitenge K (2013) Genetic variability of maize stover quality and the potential for genetic improvement of fodder value. Field Crops Research 153: 79-85.

FAO (2014)FAOStatistical Database. Food and Agricultural Organization of the United Nations Rome Italy.

Ghanem ME, Marrou H, Biradar C, Sinclair TR (2015) Production potential of lentil (Lens culinaris Medik.) in East Africa. Agricultural Systems 137:24-38.

Haddad SG, Husein MQ (2001)Nutritive value of lentil and vetch straws as compared with alfalfa hay and wheat straw for replacement ewe lambs.Small Ruminant Research 40:255-260.

Hadjipanayiotou M (1997) The role of crop residues and agroindustrial by-products in filling the deficit of animal feedstuffs in the Middle East. In: Haddad N, Tutwiler R, Thomson E (Eds.) Proceeding of the improvement of crop livestock integration in the Dry Areas of West Asia and North Africa. Amman Jordan.Pp. 372-385.

Horrocks R, Vallentine J (1999) Harvested Forages. Academic Press London UK.

Kusmenoglu I, Muehlbauer F (1998) Genetic variation for biomass and residue production in lentil: II. Factors determining seed and straw yield. Crop Science 38: 911-915.

Menke K, Raab L, Salewski A, Steingass H, Fritz D, Schneider W (1979) The estimation of the digestibility and metabolisable energy content of ruminant feeding stuffs from the gas production when they are incubated with rumen liquor. Journal of Agricultural Science 93: 217-222.

Menke K, Steingass H (1988) Estimation of the energetic feed value from chemical composition and in vitro gas production using rumen fluid. Animal Researchand Development 28:7-55.
Risco C, Melendez P (2011)Dairy Production Medicine. John Wiley and Sons New Jersey USA.

SAS (2012) SAS/STAT 12.1 User's Guide SAS Inc., Cary, NC, USA

Shrestha R, Turner NC, Siddique KHM, Turner DW (2006) Physiological and yield responses to warer deficits amomg lentil genotypes from diverse origins. Australian Journal of Agricultural Research 57:903-915.

Siddique KHM,Loss SP, Regan KL, Pritchard DL (1998) Adaptaion of lentil (Lens culinaris) to short season mediteranean type environments: Response to sowing rates. Journal of Agricultural Research 49: 1057-1066.

Singh S, Kushwaha B, Nag S, Mishra A, Bhattacharya S, Gupta $P$,Singh A (2011) In vitro methane emission from Indian dry roughages in relation to chemical composition. Current Science 101: 57-65.

Tolera A, Berg T, Sundsto IF (1998) The effect of variety on maize grain and crop residue yield and nutritive value of the stover. Animal Feed Science and Technology 79: 165-177.

Tolera A, Tsegaye B, Berg T (2008) Effect of variety, cropping year, location and fertilizer application on nutritive value of durum wheat straw. Journal of Animal Physiology and Animal Nutrition 92:121-130.

Valbuena D, Erenstein O, Tui S, Abdoulaye T, Claessens L, Duncan A, Gérard B,Rufino M, Teufel N, Rooyen A, Wijk M (2012) Conservation Agriculture in mixed crop-livestock systems: Scoping crop residue trade-offs in Sub-Saharan Africa and South Asia.Field Crop Research 132: 175-184.

Van Soest P,Robertson J (1985)Analysis of Forage and Fibrous Foods. ALaboratory Manual for Animal Science. Cornell University New York.

\section{Journal of Experimental Biology and Agriculture Science http://www.jebas.org}

